\section{RAZLOZI RAZVODA BRAKA KAO ODREDNICE SPORAZUMA $O$ RODITELJSKOJ SKRBI}

Posljednjih desetljeća stopa razvoda braka bitno se povećava u zemljama zapadnog svijeta. Ovo istraživanje nastojat će odgovoriti na sljedeća pitanja: koji su razlozi razvoda braka iz perspektive supružnika u postupku posredovanja, postoje li spolne razlike u njihovoj percepciji te pomoću kojih varijabli možemo razlikovati bračne parove koji postižu sporazum o roditeljskoj skrbi od onih parova koji ga ne postižu.

Provedena je analiza sadržaja 177 stručnih mišljenja u postupku posredovanja provedenih 2010. i 2013. godine u Centru za socijalnu skrb Zagreb, Podružnica Sesvete.

Rezultati pokazuju da su bračni partneri navodili sljedeće razloge koji su doveli do razvoda braka: Komunikacijski problemi, Emocionalno udaljavanje, $\mathrm{Ne}$ dostatak emocionalne podrške i poštovanja, Neusklađenost partnerskih očekivanja, Nedostatak instrumentalne podrške, Partnersko nasilje, Financijski problemi, Partnerovi roditelji kao izvor sukoba, Roditeljstvo kao

\footnotetext{
Ana Štifter, psihologinja, e-mail: anstifter@gmail.com

2 Marko Mihalj, psiholog, e-mail: markomihalj@outlook.com

3 doc.dr.sc. Linda Rajhvajn Bulat, psihologinja, e-mail: lindarajhvajn@net.hr

4 Silvia Vuković, psihologinja, e-mail:vukovic@duga-zagreb.hr
}

Prethodno priopćenje

Primljeno: srpanj, 2016.

Prihvaćeno: listopad, 2016.

UDK $364.46: 347.635$

DOI 10.3935/ljsr.v23i2.75

\section{Ana Štifter ${ }^{1}$}

Marko Mihalj²

Centar za socijalnu skrb Zagreb

Podružnica Sesvete

Linda Rajhvajn

Bulat $^{3}$

Sveučilište u Zagrebu

Pravni fakultet

Studijski centar socijalnog rada

Silvia Vuković ${ }^{4}$

Dom za djecu i odrasle žrtve

nasilja u obitelji »Duga-Zagreb«

Ključne riječi:

razvod braka, razlozi razvoda braka, postupak posredovanja, obiteljska medijacija, sporazum 0 roditeljskoj skrbi. 
izvor sukoba, Emocionalni/psihički problemi pojedinca i Nevjera. Od navedenih razloga, prva četiri su najčešće navođeni, tj. najzastupljeniji. Žene statistički značajno više od muškaraca kao razloge razvoda navode nedostatak instrumentalne podrške, partnersko nasilje te emocionalne/psihičke probleme pojedinca, dok se niti za jedan razlog nije pokazalo da ga statistički značajno više navode muškarci.

Dobivene varijable koje najbolje razlikuju roditelje koji su postigli sporazum o roditeljskoj skrbi od onih koji nisu, su sljedeće: Procjena stručnjaka o spremnosti supružnika na suradnju oko roditeljske skrbi, Partnersko nasilje, Komunikacijski i Emocionalni/psihički problemi, te Emocionalno udaljavanje.

Također, zanimljivost dobivenih značajnih varijabli oslanja se na moguće implikacije za korištenje obiteljske medijacije u praksi.

\section{UVOD}

Brak je zakonski i društveno uređena zajednica, obično između jednog muškarca i jedne žene, koja je regulirana zakonima, pravilima, običajima, vjerovanjima i stavovima koji propisuju prava i obaveze partnera te njihov zajednički status prema djeci (ako ih bračni partneri imaju). U Republici Hrvatskoj brak je zakonom uređena zajednica muškarca i žene (Obiteljski zakon, 2015., čl. 12.).

Unatoč pojedinim razlozima za održavanje braka, u zapadnim zemljama se posljednih desetljeća bitno povećava stopa razvoda brakova. Tako je i u Hrvatskoj u 2013. godini, prema statističkom izvješću Državnog zavoda za statistiku (2014.), broj razvedenih brakova na 1000 sklopljenih u 2013. g. iznosio 312, a deset godina ranije je taj broj bio 220. Upravo zbog takvog porasta stope razvoda s jedne strane, te važnosti braka za pojedinca i društvo s druge strane, bitno je istražiti koji su razlozi za razvod braka koje partneri procjenjuju važnijima od želje za ostankom u zajednici.

Razvod braka i njegovi učinci često se pojavljuju kao tema istraživanja, ali nisu brojna istraživanja razloga razvoda kako ih percipiraju sami supružnici koji se razvode. Rezultati takvih istraživanja (Wolcott i Hughes, 1999.; Amato i Previti, 2003.) upućuju na to da velik postotak sudionika navodi inkompatibilnost kao razlog razvoda i pri tome inkompatibilnost definiraju kao nemogućnost slaganja i nerješive razlike u interesima i životnim ciljevima. Komunikacijski problemi su u jednom istraživanju (Wolcott i Hughes, 1999.) navođeni kao najčešći razlog razvoda kod muškaraca i žena, dok je preljub u više istraživanja jedan od tri glavna razloga (Wolcott i Hughes, 1999.; Amato i Previti, 2003.). Nasilničko ponašanje partnera je također jedan od češćih razloga razvoda, a ustanovljene su statistički značajne

\section{6 članci}




\section{A. Štifter, M. Mihalj, L. Rajhvajn Bulat, S. Vuković: Razlozi razvoda braka ...}

razlike između muškaraca i žena - žene značajno češće nego muškarci navode fizičko nasilje kao glavni razlog razvoda (Wolcott i Hughes, 1999.). Vrlo slična situacija je i s navođenjem zloporabe alkohola i/ili droga kao razloga razvoda (Wolcott i Hughes, 1999.; Amato i Previti, 2003.). Istraživanje provedeno u Nizozemskoj ističe promjene motiva za razvod kroz vrijeme, čiji rezultati pokazuju da bračni partneri (više žene) posljednjih desetljeća sve manje navode nevjeru, nasilje ili ovisnosti kao glavne razloge razvoda, a sve češće inkompatibilnost, emocionalno udaljavanje, komunikacijske probleme i neslaganje u vezi brige za kućanstvo (de Graaf i Kalmijn, 2006.). Uz navedene razloge, postoje i oni koji doprinose razilaženju supružnika, a tiču se dobi u kojoj su supružnici sklopili brak, trajanja bračne zajednice, strukture obitelji, specifičnosti obitelji u kojima su supružnici odrastali, postojanje kohabitacije prije braka, religioznosti te stupnja obrazovanja (Clark i Crompton, 2006.; Härkönen, 2013.).

U svakom slučaju, prekid bračne zajednice, uključujući period prije i poslije njega, sa sobom nosi brojne promjene i potreban je izrazit psihološki napor supružnika za prilagodbu nastaloj situaciji. Činjenica da djeca doživljavaju promjene u obiteljskoj dinamici, načinu života pa i samom emocionalnom odnosu prema roditeljima te da su nerijetko izložena verbalnim konfliktima roditelja, upućuje na to da su i djeca tijekom razvoda braka izložena intenzivnom stresu (Walton, Oliver i Griffin, 1999.; Finley i Schwartz, 2009.; Hughes, 2009.) i da su posljedice često dugoročne (Amato, 2001.; Amato i Cheadle, 2005.), zbog čega im treba posvetiti posebnu pažnju. Osobita pozornost tijekom razvoda braka treba se obratiti djeci koja su svjedočila obiteljskom nasilju ili su sami bili žrtve nasilja jer su takva djeca i prije razvoda psihološki vulnerabilna (McCloskey, Figueredo i Koss, 1995.; Čudina-Obradović i Obradović, 1999.), a za vrijeme razvoda mogu biti dodatno traumatizirana pojačanim roditeljskim sukobima. U svim društvima je pitanje djece nakon razvoda uređeno bilo običajima, bilo zakonom. Za vrijeme provođenja ovog istraživanja, u Hrvatskoj je na snazi bio Obiteljski zakon iz 2003. godine (2003., 2004., 2007., 2011., 2013.) prema kojem su roditelji mlt. djece obavezni pristupiti postupku posredovanja prije razvoda braka u centru za socijalnu skrb tijekom kojeg se nastoji analizirati stanje te postići sporazum supružnika za sva ili što više spornih pitanja koja se uglavnom tiču djece (Majstorović, 2007.).

Posredovanje, kako ga je propisivao tadašnji Obiteljski zakon, imalo je cilj dvojake naravi. Prvo, ispitati razloge koji su doveli do poremećenosti bračnih odnosa te nastojati da se ti razlozi otklone i da se bračni drugovi pomire. Drugo, upoznati bračne drugove s pravnim i psihosocijalnim posljedicama razvoda braka (Majstorović, 2007.).

Sada važeći Obiteljski zakon koji je na snazi od studenog 2015. godine (2015.) umjesto postupka posredovanja prije razvoda braka, uvodi nove postupke: oba- 
vezno savjetovanje i obiteljsku medijaciju. Tijekom navedenih postupaka cilj je da roditelji sami ili uz pomoć stručnjaka postignu plan o zajedničkoj roditeljskoj skrbi, koji se potom potvrđuje sudskom odlukom. Ukoliko roditelji ne postignu sporazum, sudskom odlukom se u postupku razvoda braka određuje s kojim će roditeljem dijete stanovati, o načinu ostvarivanja roditeljske skrbi, o ostvarivanju osobnih odnosa djeteta i roditelja s kojim dijete neće stanovati i visini uzdržavanja djeteta (Obiteljski zakon, 2015., čl. 53.).

Obvezno savjetovanje definirano je kao oblik pomoći članovima obitelji da donesu sporazumne odluke o obiteljskim odnosima, vodeći posebnu brigu o zaštiti obiteljskih odnosa u kojima sudjeluje dijete te o pravnim posljedicama nepostizanja sporazuma i pokretanju sudskih postupaka u kojima se odlučuje o osobnim pravima djeteta (Obiteljski zakon, 2015., čl. 321., st. 1.). Ako roditelji ne sastave plan o zajedničkoj roditeljskoj skrbi, dužni su pristupiti prvom sastanku obiteljske medijacije, tzv. predmedijacijskom postupku čija je svrha dvojaka: s jedne strane treba pojasniti prednosti medijacije, postupak i uloge sudionika kako bi oni donijeli informiranu odluku je li medijacija za njih prikladan način rješavanja sporova i sukoba, a s druge strane za obiteljskog je medijatora to prilika procijeniti jesu li ostvarene pretpostavke za ulazak u obiteljsku medijaciju - spremnost na suradnju, kompetentnost i ravnoteža moći (Breber i Sladović Franz, 2014.). Nakon predmedijacijskog postupka, ako su ispunjene pretpostavke i ako to dobrovoljno žele, sudionici mogu odmah nastaviti s medijacijskim postupkom ili im se može dati vrijeme potrebno za promišljanje o adekvatnosti obiteljske medijacije te se u postupak može ući naknadno kada se ostvare pretpostavke (Breber i Sladović Franz, 2014.).

Obiteljska medijacija je kratkotrajni proces koji počiva na procesu rješavanja problema pregovaranjem i olakšavanju komunikacije između članova obitelji u kojem im treća osoba - obiteljski medijator pomaže u identificiranju potreba, briga i strahova te osmišljavanju izvedivih i prihvatljivih rješenja sukoba kako bi se postigao zajednički sporazum (Sladović Franz, 2005.). Glavna svrha postupka obiteljske medijacije je postizanje plana o zajedničkoj roditeljskoj skrbi i drugih sporazuma u vezi s djetetom. Uz ostvarenje te svrhe, u postupku obiteljske medijacije stranke se mogu sporazumjeti i o svim drugim spornim pitanjima imovinske i neimovinske naravi (Obiteljski zakon, 2015., čl. 331.).

Dosadašnja zakonska rješenja i postupci vezani za djecu u razvodu braka roditelja, prema starom, kao i novom Obiteljskom zakonu, vodili su se načelom zaštite dobrobiti i prava djeteta. No, potrebno je istaknuti razlike između ovih postupaka. Posredovanje se provodilo isključivo prilikom postupka razvoda braka. Za razliku od toga, obvezno savjetovanje se prema odredbama novog Obiteljskog zakona, provodi prije pokretanja postupka razvoda braka u kojem postoji zajedničko ma-

\section{8 članci}


loljetno dijete, ali i prije pokretanja ostalih sudskih postupaka o ostvarivanju roditeljske skrbi i osobnih odnosa s djetetom (Obiteljski zakon, 2015., čl. 322., st. 1.).

Obiteljska medijacija obuhvaća različite vrste obiteljskih sporova te osim supružnika i druge članove obitelji. Budući da je između različitih vrsta obiteljskih nesuglasica i sporova, razvod braka ipak najčešći primjer u praksi (Alinčić, 1999.), medijacija razvoda je najrasprostranjenija vrsta obiteljske medijacije.

Nadalje, posredovanje za razliku od obiteljske medijacije uključuje i druge aspekte bračnog odnosa, poput utvrđivanja obrazaca koji su doveli do poremećenih odnosa supružnika, ispitivanja i eventualnog otklanjanja uzroka sukoba te pokušaja mirenja. Postupak posredovanja nije u potpunosti strukturiran kao postupak obiteljske medijacije te je sudjelovanje supružnika obavezno. U posredovanju isključivo sudjeluju supružnici, odnosno roditelji, bez uključivanja drugih članova obitelji te je fokus usmjeren na upoznavanje supružnika s psihosocijalnim posljedicama razvoda braka. Konačno, posredovatelj izvršava različite profesionalne uloge, koje kolidiraju s drugim ulogama vezanim uz eventualni tretman te obitelji u centru za socijalnu skrb, stoga je u tom dijelu sama nepristranost posredovatelja jednim dijelom ugrožena (Sladović Franz, 2005.).

Svrha obiteljske medijacije, između ostalog, je postizanje dogovora između roditelja u pogledu što boljeg zbrinjavanja njihove zajedničke djece nakon razvoda braka. Medijacija je strukturiran proces u koji se ulazi dobrovoljno. Obuhvaća različite vrste obiteljskih sporova te je moguće sudjelovanje svih članova obitelji. Medijacija je usmjerena na potrebe, interese i brigu o maloljetnoj djeci, dok samo odlučivanje počiva na sudionicima, odnosno roditeljima u većini slučajeva. Također, usmjerena je na rješavanje konkretnih praktičnih problema, a ne obiteljskih problema iz prošlosti. Bitno je naglasiti nepristranost medijatora koji izvršava isključivo tu profesionalnu ulogu u cijelom procesu (Sladović Franz, 2005.).

Sporazum o roditeljskoj skrbi, kao rezultat i postupka posredovanja i postupka obiteljske medijacije, podrazumijeva dogovor roditelja s kojim će od njih zajedničko dijete/djeca živjeti nakon razvoda braka, a s kojim će ostvarivati osobne kontakte (susreti na dnevnoj, mjesečnoj i godišnjoj razini) te koliko će roditelj s kojim dijete ne živi financijski doprinositi za dječje potrebe (visina alimentacijskih troškova). Proces postizanja dogovora u vezi djece može biti izrazito dugačak i bolan, osobito za djecu koja se nalaze u središtu sukoba, te je od posebnog interesa psihologa i drugih stručnjaka usmjerenih na psihosocijalnu dimenziju pojedinca. Prema istraživanju postupaka donošenja odluke o daljnjoj skrbi za djecu nakon razvoda provedenom u Hrvatskoj, u 17\% slučajeva nije postignut dogovor roditelja o tome s kojim će roditeljem živjeti dijete, a u 33\% slučajeva dogovor nije postignut u vezi alimentacije (Laklija, Pećnik i Sarić, 2005.). 
Istraživanja u drugim zemljama pokazuju različit uspjeh u postizanju dogovora, no redovito se radi o istraživanjima učinaka medijacije na koju su upućeni parovi koji prilikom pokretanja razvoda braka nisu imali sporazum o djeci. U Hrvatskoj se, kao što je već navedeno, provodio postupak posredovanja prije razvoda braka u kojem su sudjelovali i parovi koji su se sami dogovorili o djeci tako da se očekuje nešto veći postotak dogovora zbog različitog uzorka. Kelly (2004.) u komparativnoj studiji devet istraživanja postupaka medijacije provedenih diljem SAD-a navodi podatak od $50 \%$ do $90 \%$ postignutih roditeljskih sporazuma koji se tiču djece. U istraživanju u kojem je pola uzorka izvještavalo o obiteljskom nasilju, a druga polovica nije, postotak postignutih sporazuma je manji i iznosi 46\% (Mathis i Tanner, 1998.).

Nepostizanje dogovora u vezi djece je gotovo redovito praćeno sukobima i/ili manipulacijama roditelja koji dodatno povećavaju negativne efekte razvoda braka na mentalno zdravlje djece, zbog čega je važno istražiti koji su faktori povezani s postizanjem dogovora. Osim karakteristika samog postupka medijacije i/ili posredovanja prije razvoda braka, za ishode takvih postupaka su važne i karakteristike bračnih partnera i/ili partnerskog odnosa. Naime, izraelsko istraživanje (Cohen, 2012.) pokazuje da je nakon postupka medijacije sporazum (barem oko jednog pitanja u vezi djece) postiglo $45 \%$ parova, pri čemu su dogovor češće postizali ljudi mlađe dobi, oni koji su kraće u braku, imućniji, oni s boljim pregovaračkim vještinama te parovi kod kojih se oboje žele razvesti. Kelly (2004.) navodi da sporazum češće postižu roditelji jednog djeteta, za razliku od onih koji imaju dvoje ili više djece.

Cilj ovog rada je istražiti jesu li karakteristike roditelja, a osobito karakteristike njihovog partnerskog odnosa te percipirani razlozi razvoda braka supružnika povezani s njihovom spremnošću da postignu dogovor o roditeljskoj skrbi te kojim varijablama se najbolje može razlikovati parove koje postižu sporazum o roditeljskoj skrbi od onih koji ga ne postižu, kao i postoje li spolne razlike u percipiranju razloga razvoda braka kod supružnika. Uz to, pretpostavlja se kako će ovo istraživanje doprinijeti praktičnim implikacijama u pogledu postupaka prije razvoda braka, bilo da se radi o već poznatom postupku posredovanja ili novom postupku obiteljske medijacije.

\section{METODA}

\section{Uzorak}

Istraživanje je provedeno u Centru za socijalnu skrb Zagreb (Podružnica Sesvete) koristeći prigodno dostupna stručna mišljenja postupka posredovanja prije razvoda braka tijekom 2010. i 2013. godine. Uzorak se sastojao od ukupno 177 jedinica analize, odnosno sekundarno analiziranih podataka o toliko bračnih paro-

\section{0 članci}




\section{A. Štifter, M. Mihalj, L. Rajhvajn Bulat, S. Vuković: Razlozi razvoda braka ...}

va koji su prošli postupak posredovanja (89 parova u 2010. godini te 88 parova u 2013. godini).

Prosječna dob muškaraca iz analiziranih bračnih parova je 39 godina ( $M=$ $39,30, S D=8,69$; raspon od 21 do 66 godina), dok je prosječna dob žena 37 godina ( $M=37,15, S D=8,50$; raspon od 20 do 60 godina). Postupak posredovanja prije razvoda braka pokretale su uglavnom žene (56,5\%), nakon toga zajednički, oba supružnika (32,8\%) te najmanje muškarci $(10,7 \%)$. Prosječno trajanje braka je 13 godina ( $M=13,20, S D=7,96$; raspon od 1 do 39 godine).

Od ukupno 177 muškaraca, 1,1\% njih nema završenu osnovnu školu, 13,6\% ima završenu osnovnu školu, 77,8\% ima završenu srednju školu te 7,4\% ima viši ili visoki stupanj obrazovanja. Od ukupno 177 žena, 1,7\% nema završenu osnovnu školu, 10,7\% ima završenu osnovnu školu, 69,5\% ima završenu srednju školu, dok $18,1 \%$ ima viši ili visoki stupanj obrazovanja. Veći broj muškaraca i žena su radno aktivni i zaposleni ( $\mathrm{M}$ i $\breve{Z}=77 \%$ ), dok je manji broj njih u mirovini $(\mathrm{M}=6,3 \%, \check{Z}=$ 3,4\%). Parovi uglavnom imaju dvoje djece (39\%), njih 37,9\% jedno dijete, $15,8 \%$ parova ima troje djece, a vrlo mali postotak njih $(6,3 \%)$ četvero i više djece, dok samo $1,1 \%$ parova nema djece.

U pogledu aspekta s kojim roditeljem djeca žive nakon pokretanja postupka razvoda braka, vidljivo je kako djeca nastavljaju živjeti uglavnom s majkom (71,3\%), dok s ocem mnogo manje (8,5\%). Ipak, dio djece nastavlja živjeti s oba roditelja $(13,6 \%)$, dok je 3,4\% djece razdvojeno, tj. jedno dijete živi s majkom, drugo s ocem. Pet parova u postupku posredovanja imalo je odraslu djecu $(2,8 \%)$. Za kraj, bitno je naglasiti kako je 78,6\% parova tijekom postupka posredovanja uspjelo postići sporazum o roditeljskoj skrbi, dok njih $21,4 \%$ nije postiglo sporazum.

\section{Postupak prikupljanja podataka i instrumentarij}

Prije korištenja stručnih mišljenja u svrhu istraživanja, zatražena je suglasnost svih rukovodećih osoba, odnosno Centra za socijalnu skrb Zagreb, te je cijeli proces podrazumijevao slijeđenje etičkih principa struke, kao i načela tajnosti i zaštite osobnih podataka korisnika u sustavu socijalne skrbi prema važećem Zakonu o socijalnoj skrbi.

Postupak istraživanja uključivao je dva dijela - kvalitativni i kvantitativni. Stručno mišljenje sadržavalo je sociodemografske varijable, obiteljsku povijest, obilježja braka i obitelji, obilježja razvoda, podatke o percipiranim razlozima razvoda braka, kao i podatak o (ne)postignutom sporazumu o roditeljskoj skrbi. Tijekom postupka posredovanja, oba supružnika trebala su odgovoriti na otvoreno pitanje »Koji su razlozi za razvod braka?« te su mogli navoditi jedan ili više razloga. Njihovi odgovori zabilježeni su u stručnom mišljenju. 
Kvalitativnoj analizi sadržaja stručnih mišljenja prethodila je kvantifikacija, tj. brojanje učestalosti pojavljivanja pojedinog percipiranog razloga za razvod braka, za što je kreirana provjerna lista kao temelj za kasniju analizu sadržaja. Jedinica analize bila su stručna mišljenja o posredovanju prije razvoda braka, sastavljena od strane psihologa i socijalnih radnika, Centra za socijalnu skrb Zagreb, Podružnice Sesvete u 2010. godini. Iz uzorka ( $N=89)$ 2010. g. su za kvalitativnu analizu isključena stručna mišljenja za 12 parova koji su odbili izjasniti se o razlozima razvoda braka stoga je kvalitativna obrada izvršena na uzorku od 77 stručnih mišljenja. Iz stručnih mišljenja apstrahirani su razlozi poremećaja bračnih odnosa koje su supružnici navodili, koji u prvom koraku predstavljaju pojmove (Tablica 1.1. u Prilogu $)^{4}$, u drugom koraku su pojmovi razvrstani u kategorije, dok su u posljednjem trećem koraku kategorije sažete u općenitije teme (Tablica 1.).

Kako bi se podaci dobiveni kvalitativnom analizom povezali s drugim, kvantitativnim podacima, za svaku je kategoriju zabilježeno navodi li ju pojedini bračni partner kao razlog prekida njegovog/njenog braka (kategorije dobivene na podacima prikupljenim 2010. godine korištene su kao referentni okvir za kategoriziranje podataka iz 2013. godine).

Apstrahirani podaci iz 2010. g. prikazani su na međunarodnoj konferenciji hrvatskih psihologa 2012. g. (»Psihološki aspekti suvremene obitelji, braka i partnerstva«) te su kasnije služili kao referentni okvir za kategorizaciju novih apstrahiranih podataka u 2013. g., koja je odabrana kao zadnja godina u kojoj su provođeni isključivo postupci posredovanja prije razvoda braka, prije stupanja na snagu Obiteljskog zakona iz 2014., odnosno uvođenja novih postupaka - obveznog savjetovanja i obiteljske medijacije. Dodatno, podaci iz 2013. g. apstrahirani su također i kao najrelevantniji u proteku vremena od 2010. g., kako bi se time uvažile eventualno nastale značajne sociodemografske promjene uzorka (sudionika), a uzimajući u obzir trend rasta i dinamike migracija stanovništva na području Sesveta zadnjeg desetljeća. Odabir kalendarskih godina u kojima su apstrahirani podaci ovisio je o završetku i arhiviranju postupaka posredovanja u Centru za socijalnu skrb. Primjerice, prvi podaci apstrahirani su u prvom kvartalu 2012. g. kada nisu bili završeni svi postupci posredovanja iz 2011. g., stoga je bilo nužno uzeti podatke iz 2010. g., kako bi se postigao željeni kriterij obuhvaćanja svih (završenih i arhiviranih) postupaka posredovanja u određenoj godini.

Nadalje, iz svih stručnih mišljenja apstrahirani su i ostali potrebni podaci koji su korišteni i prikazani u rezultatima, a tiču se već navedenih sociodemografskih varijabli, pojedinih kvantitativnih varijabli te podataka o (ne)postignutom sporazumu o roditeljskoj skrbi.

${ }^{4}$ Prilozi će biti objavljeni na mrežnim stranicama časopisa u online izdanju ovog rada

\section{2 članci}




\section{A. Štifter, M. Mihalj, L. Rajhvajn Bulat, S. Vuković: Razlozi razvoda braka ...}

Postavljeno istraživačko pitanje kvalitativnog dijela ovog istraživanja bilo je (1) »Koji su razlozi razvoda braka iz perspektive bračnih partnera?«, dok su problemi kvantitativnog dijela istraživanja glasili (2) »lspitati spolne razlike u percepciji supružnika vezanoj uz razloge razvoda braka« te (3) »Ispitati pomoću kojih varijabli možemo razlikovati bračne parove koji postižu sporazum o roditeljskoj skrbi od onih parova kod kojih isti izostaje«.

\section{REZULTATI}

Na postavljeno pitanje »Koji su razlozi razvoda braka iz perspektive bračnih partnera?« nastojalo se dobiti odgovor kvalitativnom analizom sadržaja, koju je slijedila kvantifikacija, tj. brojanje učestalosti pojavljivanja pojedinog razloga.

Tablica 1. Kvalitativna analiza sadržaja razloga razvoda braka iz perspektive bračnih partnera (kategorije, teme)

\begin{tabular}{|c|c|}
\hline Kategorija & Tema \\
\hline Komunikacijski problemi & \multirow{5}{*}{ Obilježja partnerskog odnosa } \\
\hline Emocionalno udaljavanje & \\
\hline Nedostatak emocionalne podrške i poštovanja & \\
\hline Nedostatak instrumentalne podrške & \\
\hline Partnersko nasilje & \\
\hline Financijski problemi & \multirow{3}{*}{ Vanjske okolnosti } \\
\hline Partnerovi roditelji kao izvor sukoba & \\
\hline Roditeljstvo kao izvor sukoba & \\
\hline Neusklađenost partnerskih očekivanja & \multirow{2}{*}{ Individualne osobine bračnih partnera } \\
\hline Emocionalni/psihički problemi pojedinca & \\
\hline Nevjera & \\
\hline
\end{tabular}

Kao što se može vidjeti, analiza sadržaja vezana uz razloge razvoda braka dala je tri teme:

1. obilježja partnerskog odnosa:

- komunikacijski problemi

- emocionalno udaljavanje

- nedostatak emocionalne podrške i poštovanja

- nedostatak instrumentalne podrške

- partnersko nasilje

2. vanjske okolnosti

- financijski problem

- partnerovi roditelji kao izvor sukoba

- roditeljstvo kao izvor sukoba 
3. individualne osobine bračnih partnera:

- neusklađenost partnerskih očekivanja

- emocionalni/psihički problemi pojedinca

Kako kategorija nevjera sadržajno može odgovarati svakoj od navedenih tema (jer se odnosi i na odnos između partnera, uključuje vanjske osobe, a može ovisiti i o individualnim osobinama pojedinog partnera), ostala je kao zasebna kategorija, koja ima specifičan značaj za razumijevanje prekida bračnog odnosa. U literaturi se također učestalo razlog bračne nevjere ostavlja kao izdvojena kategorija kojoj se pridaje posebna važnost (Wolcott i Hughes, 1999.; Amato i Previti, 2003.).

Slijedi prikaz navedenih (percipiranih) razloga razvoda braka od strane supružnika (Slika 1.).

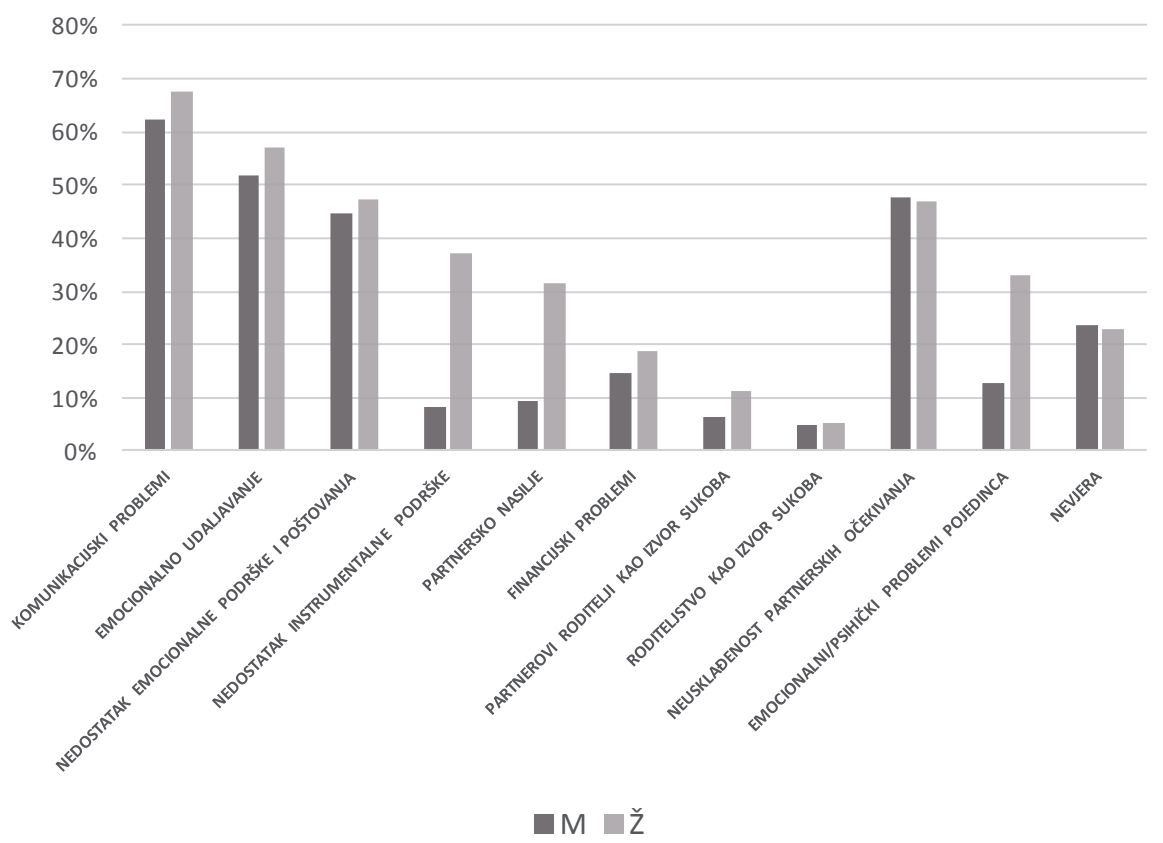

Slika 1. Prikaz učestalosti i raspodjela po spolu razloga razvoda braka iz perspektive bračnih partnera

Drugi problem tiče se upravo spolnih razlika. Žene statistički značajno više od muškaraca kao razloge razvoda navode nedostatak instrumentalne podrške (t-test za proporcije iznosi $t=-6,474$, uz $d f=170$ i $p<0,01)$, partnersko nasilje $(t=-6,354$, $\mathrm{df}=170, \mathrm{p}<0,01)$ te emocionalne/psihičke probleme pojedinca $(\mathrm{t}=-4,736, \mathrm{df}=$ $170, p<0,01)$, dok se niti za jedan razlog nije pokazalo da ga statistički značajno 
više navode muškarci. Za ostale razloge između muškaraca i žena također ne postoji statistički značajna razlika u proporciji njihovog navođenja. Ukoliko se pogledaju ukupni razlozi po temama, i muškarci i žene kao najčešće razloge razvoda braka navode obilježja partnerskog odnosa.

Razmatrajući koliko se supružnici međusobno slažu u navođenju da je određeni razlog taj koji je doveo do problema u braku ili nije, uvidjelo se kako najveće razilaženje u mišljenjima postoji za nedostatak instrumentalne podrške (71, odnosno $41,5 \%$ bračnih partnera se u tome ne slaže), emocionalne/psihičke probleme pojedinca $(33,9 \%)$ te nedostatak emocionalne podrške i poštovanja $(32,8 \%)$.

Treći postavljeni problem ovog rada bio je provjeriti kojim varijablama možemo razlikovati skupine bračnih partnera koji postižu sporazum o roditeljskoj skrbi od onih koji ga ne postižu. Kako bismo dobili odgovor na postavljeni problem, provedena je diskriminativna analiza, statistički postupak kojim se nastoji dobiti što bolja deskripcija razlika između dvije navedene grupe, tj. kombinacija varijabli koja in može najbolje razlikovati (Tabachnik i Fidell, 2007.). Kako bi se provjerilo mogu li se subuzorci iz 2010. i 2013. godine tretirati kao jedinstveni uzorak, provjereno je razlikuju li se u relevantnim sociodemografskim obilježjima (dob, obrazovanje, zaposlenje, broj djece, raniji brak, trajanje braka, trajanje predbračne veze, postojanje kohabitacije i trudnoće prije braka) te u broju postignutih sporazuma o roditeljskoj skrbi. S obzirom na to da između podataka prikupljenih u dvije različite godine ne postoje statistički značajne razlike u navedenim varijablama, u diskriminativnu analizu uključena su oba subuzorka zajedno, tj. 177 sekundarno analiziranih podataka tolikog broja bračnih parova. Prvi korak diskriminativne analize uključio je univarijatne analize na svim diskriminativnim varijablama, što je prikazano u Tablici 2.1. u Prilogu. ${ }^{*}$

Provedena diskriminativna analiza rezultirala je jednom diskriminativnom funkcijom koja dobro razlikuje ove dvije skupine, što pokazuje kanonička korelacija između diskriminativnih varijabli i pripadnosti pojedinoj skupini (Tablica 2.).

Tablica 2. Test značajnosti diskriminativne analize pomoću Wilksove lambde, svojstvene vrijednosti diskriminativne funkcije, postotka objašnjenog međugrupnog varijabiliteta i koeficijenta kanoničke korelacije $(N=177)$

\begin{tabular}{ccccc}
\hline $\begin{array}{c}\text { Svojstvena } \\
\text { vrijednost }\end{array}$ & $\begin{array}{c}\text { \% Objašnjene } \\
\text { varijance }\end{array}$ & $\begin{array}{c}\text { Koeficijent } \\
\text { kanoničke } \\
\text { korelacije }\end{array}$ & $\begin{array}{c}\text { Wilks } \\
\text { lambda }\end{array}$ & $\mathbf{X}^{2}$ \\
\hline 1,220 & 100,0 & 0,741 & 0,450 & $95,318^{* *}$ \\
\hline$" \mathrm{p}<0,01$ & & & \\
\end{tabular}

* Prilozi će biti objavljeni na mrežnim stranicama časopisa u online izdanju ovog rada 
Vrijednost Wilksove lambde, kao i vrijednost hi-kvadrata pokazuje da su razlike među skupinama, kada se uzmu sve navedene varijable zajedno, statistički značajne uz rizik manji od $1 \%$ te je opravdano izvođenje diskriminativne funkcije. Uz to, temeljem koeficijenta kanoničke korelacije, možemo zaključiti da postoji povezanost između postizanja sporazuma o roditeljskoj skrbi i opisanog skupa diskriminativnih varijabli koji objašnjava gotovo $55 \%$ kriterija. Također, na osnovi ove diskriminativne funkcije možemo točno prognozirati $95,7 \%$ uzorka, odnosno točno možemo razvrstati $92 \%$ bračnih partnera koji nisu postigli sporazum o roditeljskoj skrbi i 96,6\% onih koji jesu. Međutim, analizirajući ove podatke, trebamo voditi računa o tome da su skupine vrlo disproporcionalne po broju sudionika koje uključuju pa je i po samom slučajnom odabiru znatno veća vjerojatnost da će neki bračni partneri postići sporazum nego da neće. Osim toga, riječ je o velikom broju varijabli kojima nastojimo predvidjeti kojoj skupini će koji bračni par pripasti, što može povećati točnost prognoze.

UTablici 3. prikazani su koeficijenti diskriminativne funkcije pomoću kojih možemo razmotriti pojedinačni odnos diskriminativnih varijabli s formiranom diskriminativnom funkcijom.

Tablica 3. Standardizirani koeficijenti i koeficijenti strukture

\begin{tabular}{lcc}
\hline \multicolumn{1}{c}{ Diskriminativna varijabla } & $\begin{array}{c}\text { Standardizirani } \\
\text { koeficijenti }\end{array}$ & $\begin{array}{c}\text { Koeficijenti } \\
\text { strukture }\end{array}$ \\
\hline $\begin{array}{l}\text { Procjena stručnjaka o spremnosti supružnika na su- } \\
\text { radnju oko roditeljske skrbi }\end{array}$ & $-0,674$ & $-0,411$ \\
\hline Partnersko nasilje - Ž & 0,371 & 0,302 \\
\hline Partnersko nasilje - M & $-0,035$ & 0,241 \\
\hline Emocionalni/psihički problemi pojedinca - M & 0,318 & 0,196 \\
\hline Komunikacijski problemi - M & 0,355 & 0,191 \\
\hline Emocionalno udaljavanje - Ž & 0,530 & 0,184 \\
\hline Zajednički život poslije pokretanja razvoda & 0,503 & 0,134 \\
\hline Raniji brak žene & 0,064 & 0,132 \\
\hline Nedostatak emocionalne podrške i poštovanja - M & 0,301 & 0,131 \\
\hline Emocionalni/psihički problemi pojedinca - Ž & 0,123 & 0,125 \\
\hline Trajanje predbračne veze u mjesecima & 0,363 & 0,113 \\
\hline Obrazovanje muža & $-0,143$ & 0,100 \\
\hline Nedostatak emocionalne podrške i poštovanja - Ž & $-0,230$ & 0,100 \\
\hline Partnerovi roditelji kao izvor sukoba - M & 0,445 & 0,097 \\
\hline Odnos žene s majkom & 0,153 & 0,089 \\
\hline Samostalan život supružnika & 0,176 & 0,084 \\
\hline Nedostatak instrumentalne podrške - Ž & 0,089 & 0,084 \\
\hline Komunikacijski problemi - Ž & $-0,220$ & 0,084 \\
\hline
\end{tabular}


A. Štifter, M. Mihalj, L. Rajhvajn Bulat, S. Vuković: Razlozi razvoda braka ...

\begin{tabular}{lcc}
\hline Nedostatak instrumentalne podrške - M & $-0,004$ & 0,081 \\
\hline Raniji brak muža & 0,212 & 0,078 \\
\hline Partnerovi roditelji kao izvor sukoba - Ž & 0,221 & 0,073 \\
\hline Obrazovanje žene & 0,084 & 0,068 \\
\hline Neusklađenost partnerskih očekivanja - Ž & 0,363 & 0,060 \\
\hline Prisutnost trećih osoba - Ž & 0,194 & 0,046 \\
\hline Godine trajanja braka & 0,151 & 0,035 \\
\hline Odnos žene s ocem & 0,073 & 0,033 \\
\hline Broj djece & $-0,093$ & 0,028 \\
\hline Razvod ženinih roditelja & 0,100 & 0,009 \\
\hline Odnos muža s majkom & $-0,091$ & 0,009 \\
\hline Prisutnost trećih osoba - M & 0,075 & $-0,001$ \\
\hline Razvod muževih roditelja & 0,022 & $-0,004$ \\
\hline Predbračna trudnoća & $-0,168$ & $-0,034$ \\
\hline Neusklađenost partnerskih očekivanja - M & $-0,279$ & $-0,036$ \\
\hline Odnos muža s ocem & 0,018 & $-0,040$ \\
\hline Emocionalno udaljavanje - M & $-0,208$ & $-0,050$ \\
\hline Financijski problemi - M & $-0,059$ & $-0,060$ \\
\hline Roditeljstvo kao izvor sukoba - Ž & $-0,342$ & $-0,081$ \\
\hline Roditeljstvo kao izvor sukoba - M & $-0,144$ & $-0,081$ \\
\hline Financijski problemi - Ž & $-0,317$ & $-0,108$ \\
\hline
\end{tabular}

Temeljem koeficijenata strukture (Tablica 3.) možemo vidjeti da najveću povezanost s diskriminativnom funkcijom koja maksimalno razlikuje skupine bračnih partnera ovisno o tome jesu li postigli sporazum o roditeljskoj skrbi, imaju varijable procjena stručnjaka o spremnosti supružnika na suradnju oko roditeljske skrbi, percepcije i muža i žene da je razlog razvoda braka partnersko nasilje, percepcije muža da su razlog razvoda braka emocionalni/psihički problemi pojedinca i komunikacijski problemi, te varijabla percepcije žene da je emocionalno udaljavanje izvor sukoba koji je doveo do razvoda braka. Pri tome se pokazalo da je pripadnost grupi koja je postigla sporazum o roditeljskoj skrbi karakterizirana time što su bivši bračni partneri u procesu prekida braka imali bolju suradnju oko roditeljske skrbi te se svi navedeni značajni razlozi poremećaja bračnog odnosa u toj skupini navode rjeđe. Zanimljivo je da dodatna diskriminativna analiza, koja uključuje samo ovih šest statistički značajnih diskriminativnih varijabli, točno razvrstava $85,1 \%$ bračnih parova na one koji jesu i one koji nisu postigli sporazum, što nije velika razlika od ranije navedenih $96 \%$ (postotkom dobivenim ovdje opisanom diskriminativnom analizom). 


\section{RASPRAVA}

U mnogim zapadnim državama, prekid bračne zajednice (razvod) sve češće biva učestali proces obiteljske dinamike. $U$ tom pogledu, nužno je ustanoviti razloge koji dovode do razvoda braka te koji se kasnije mogu odraziti u suradnji roditelja u ostvarivanju potreba njihove zajedničke djece i drugih relevantnih dogovora vezanih za djecu nakon razvoda braka.

Kako bi se odgovorilo na pitanje zašto se supružnici razvode, provedena je analiza sadržaja stručnih mišljenja u postupku posredovanja u Centru za socijalnu skrb Zagreb, Podružnici Sesvete 2010. i 2013. godine, kao što je prethodno opisano. Rezultati ovog istraživanja pokazuju da su parovi navodili sljedeće uzroke koji su doveli do razvoda braka: Komunikacijski problemi, Emocionalno udaljavanje, Nedostatak emocionalne podrške i poštovanja, Neusklađenost partnerskih očekivanja, Nedostatak instrumentalne podrške, Partnersko nasilje, Financijski problemi, Partnerovi roditelji kao izvor sukoba, Roditeljstvo kao izvor sukoba, Emocionalni/psihički problemi pojedinca i nevjera. Od navedenih razloga, prva četiri su najčešće navođena, tj. najzastupljenija.

Slične razloge razvoda braka svojim istraživanjem dobili su Wolcott i Hughes (1999.): komunikacijski problemi, neusklađenost, nevjera, fizičko nasilje, zlouporaba alkohola ili droge, emocionalno ili verbalno nasilje, financijski problemi, posao/ vrijeme, utjecaj šire obitelji, fizičko/mentalno zdravlje, ličnost partnera, problemi s djecom i ostalo. Amato i Previti (2003.) na pitanje sudionika zašto su se razveli, dobivaju sljedeće razloge: nevjera koja je najzastupljeniji razlog, potom slijedi neusklađenost partnerskih očekivanja, alkohol/droga, udaljavanje, ličnost, komunikacijski problemi i nasilje. U skladu s prethodno navedenim, dobiveni su slični rezultati razloga razvoda braka, unatoč velikim kulturalnim, društvenim i povijesnim razlikama između Hrvatske, Australije i Amerike, gdje su istraživanja provedena.

Kada pogledamo postoji li razlika u percipiranju razloga za razvod braka s obzirom na spol, rezultati pokazuju da žene statistički značajno više od muškaraca kao razlog navode nedostatak instrumentalne podrške, partnersko nasilje te emocionalne/psihičke probleme pojedinca, dok se niti za jedan razlog nije pokazalo da ga statistički značajno više navode muškarci. Istraživanja pokazuju da žene značajno češće nego muškarci navode fizičko nasilje kao glavni razlog razvoda (Wolcott i Hughes, 1999.; de Graaf i Kalmijn, 2006.).

Rezultati ovog istraživanja također pokazuju da su najčešći razlozi koje navode bračni parovi komunikacijski problemi i emocionalno udaljavanje. Navedeno ukazuje na praktične implikacije ovog istraživanja koje govore o potrebi preventivnih $\mathrm{i}$ intervencijskih programa, s ciljem poboljšanja partnerske komunikacije. Na to ukazuje istraživanje Blažeke Kokorić (2007.) koja zaključuje da je rad na partnerskim

\section{8 članci}




\section{A. Štifter, M. Mihalj, L. Rajhvajn Bulat, S. Vuković: Razlozi razvoda braka ...}

sukobima nezaobilazni dio tretmana parova te kako postoji potreba za sustavnim uvođenjem programa prevencije i savjetovališnog rada radi unaprjeđenja vještina partnera za konstruktivno rješavanje sukoba. Treba istaknuti mogućnost upotrebe obiteljske medijacije i kao preventivne usluge u svrhu pružanja pravovremene pomoći za rješavanje konkretnih sukoba koji mogu dovoditi do trajnijih poremećaja bračnih odnosa, a ne samo nakon što je već pokrenut ili se namjerava pokrenuti postupak razvoda braka. Kako navode Ajduković i Sladović Franz (2003.), suvremeni pristup sukobima polazi od spoznaje da je sukob neizbježan dio života, a prije svega dio svake promjene te može biti koristan i pridonijeti razvoju kvalitetnijih odnosa. Prema tome, da bi se sukob konstruktivno riješio, potrebno je koristiti različite pregovaračke i komunikacijske vještine te u nemogućnosti samostalnog rješavanja nastalog nesporazuma moguće je pomoć tražiti od treće neutralne strane (Breber i Sladović Franz, 2014.). Upravo medijacija kroz svoju strukturu i pravila rada može osigurati međusobno poštovanje, jednakost i pravednost te olakšati komunikaciju između sukobljenih strana (Sladović Franz, 2010.).

Treći istraživački problem ovog rada bio je provjeriti pomoću kojih varijabli najbolje možemo razlikovati bračne partnere koji postižu sporazum o roditeljskoj skrbi od onih koji ga ne postižu. Varijable koje su se u diskriminativnoj analizi pokazale značajnima su procjena stručnjaka o spremnosti supružnika na suradnju oko roditeljske skrbi, percepcije muževa i žena da je razlog razvoda partnersko nasilje, percepcija muževa da su razlozi razvoda braka komunikacijski i emocionalni/psihički problemi, te percepcija žena da je emocionalno udaljavanje izvor sukoba koji je doveo do razvoda braka.

Zamjetno je kako dobivene varijable tematski, generalno gledano, zapravo pripadaju obilježjima partnerskog odnosa koje su partneri iznosili kao najčešće razloge razvoda braka (komunikacijski problemi, emocionalno udaljavanje, partnersko nasilje), ukoliko su bili prisutni kao razlog koji je doveo do pokretanja postupka posredovanja. Varijabla emocionalni/psihički problemi pojedinca tematski pripada individualnim osobinama bračnih partnera, dok varijabla procjena stručnjaka o spremnosti supružnika na suradnju oko roditeljske skrbi nije kvalitativnom metodom kategorizirana kao razlog razvoda braka, već kao zasebna varijabla procijenjena od strane stručnjaka. Ujedno, izraženu prisutnost navedenih varijabli (razloga razvoda braka) možemo tumačiti kao moguće razloge zbog kojih supružnici nisu postizali dogovor oko djece, odnosno sporazum o roditeljskoj skrbi.

\section{Suradnja roditelja}

Možemo reći kako je procjena stručnjaka o spremnosti supružnika na suradnju oko roditeljske skrbi očekivani rezultat, odnosno kako roditelji koji su od strane 
stručnjaka procijenjeni da bolje surađuju više postižu sporazume u odnosu na roditelje za koje je procijenjeno da suradnja često izostaje.

U smislu praktičnih implikacija vezanih uz ovaj aspekt, vidljivo je kako unatoč postupcima zakonskog okvira razvoda braka, velika uloga i dalje ostaje na pojedinačnoj odgovornosti supružnika u vidu što kvalitetnijeg razrješavanja partnerskog odnosa, kao i njihove roditeljske uloge nakon razvoda. U tom kontekstu, važno je naglasiti pozitivne učinke medijacijskog procesa naspram postupka posredovanja, u kojem je značajno viša razina fokusa stavljena na odgovornost roditelja kao glavnih aktera tog procesa.

Dobiveni nalaz je također vrijedan jer pokazuje važnost provođenja predmedijacijskog postupka te pažljive procjene stručnjaka jesu li ostvarene pretpostavke za ulazak u obiteljsku medijaciju - spremnost na suradnju, kompetentnost i ravnoteža moći. U obiteljsku medijaciju mogu ući samo osobe koje su zaista spremne na suradnju i žele se dogovoriti, osobe koje su kompetentne i sposobne postići i provoditi sporazum te koje su u dovoljnoj ravnoteži moći koja osigurava ravnopravne pregovore (Breber i Sladović Franz, 2014.).

\section{Partnersko nasilje i emocionalni/psihički problemi}

Analiza roditeljskih dogovora u procesu medijacije ovisno o postojanju i stupnju obiteljskog nasilja pokazuje da su parovi kod kojih jedan roditelj izvještava o intenzivnom nasilju (upotreba oružja, premlaćivanje, silovanje, prijetnje) rjeđe postizali dogovor za razliku od onih koji ne prijavljuju nasilje ili prijavljuju nasilje slabijeg intenziteta (Beck, Walsh i Weston, 2009.). U istraživanju koje analizira dogovore u medijaciji kod obitelji koje prijavljuju određene tipove partnerskog nasilja pronađena je povezanost razine nasilja i postizanja dogovora o djeci (Kelly i Johnson, 2008.). Rezultati ovog istraživanja u skladu su s nalazima navedenih istraživanja, odnosno roditelji koji su kao razloge razvoda braka navodili partnersko nasilje rjeđe su postizali dogovor o roditeljskoj skrbi.

Nadalje, parovi kod kojih su razlog razvoda bili emocionalni/psihički problemi također su manje postizali sporazum o roditeljskoj skrbi. Za pojedinca koji ima ovakvih poteškoća postoji vjerojatnost kako nije u stanju zastupati svoje interese i potrebe na adekvatan način u medijacijskom ili nekom drugom procesu. $U$ tom smislu, nužno je obratiti pozornost na nalaz o varijabli partnerskog nasilja, ali i o varijabli emocionalni/psihički problemi, u vidu praktičnih implikacija, odnosno predmedijacijskog postupka kada je potrebno procjenjivati prikladnost upućivanja roditelja u postupak obiteljske medijacije, odnosno procjene kakva je ravnoteža moći supružnika. Prema Kelly (1995.), potrebno je osigurati ravnotežu moći između glavnih aktera procesa za ulazak u medijaciju.

\section{0 članci}




\section{A. Štifter, M. Mihalj, L. Rajhvajn Bulat, S. Vuković: Razlozi razvoda braka ...}

Prema novom Obiteljskom zakonu (2015., čl. 332., st. 1.), obiteljska medijacija se ne provodi: u slučajevima kada prema procjeni stručnog tima centra za socijalnu skrb ili obiteljskog medijatora nije moguće ravnopravno sudjelovanje bračnih drugova u postupku obiteljske medijacije, ako su jedan ili oba bračna druga lišeni poslovne sposobnosti, a nisu u stanju shvatiti značenje i pravne posljedice postupka ni uz stručnu pomoć te ako su nesposobni za rasuđivanje.

Neki stručnjaci (Gribben, 1990.; Clarke i Davies, 1992.) smatraju kako se obiteljska medijacija nikad ne provodi u situaciji obiteljskog nasilja, no drugi navode kako je ključno pitanje osjeća li se žrtva ugroženo (tada obiteljska medijacija nije moguća zbog velike neravnoteže moći) te je pojedincu potrebno pružiti mogućnost izbora za sudjelovanje ukoliko može bez straha zastupati svoje interese (Flynn, 2005.).

\section{Komunikacijski problemi}

Kao što je prethodno opisano u prvom istraživačkom problemu, komunikacijski problemi su najčešće navođeni od strane supružnika kao razlozi razvoda braka. Evidentno je kako roditelji koji nisu bili u mogućnosti održavati primjerenu komunikaciju, koja je izravno povezana s njihovom suradnjom, u većini slučajeva nisu postizali sporazum o roditeljskoj skrbi. Pretpostavljamo kako supružnici nisu naučili kvalitetno komunicirati i rješavati sukobe tijekom predbračnog i bračnog odnosa, što implicira potrebu preventivnih i intervencijskih programa u lokalnoj zajednici s ciljem poboljšanja partnerske komunikacije te usvajanja vještina rješavanja sukoba. lako u Gradu Zagrebu postoje mnogi programi i intervencije vezane uz rješavanje problematike nakon razvoda braka, deficitaran je broj onih organizacija koje isključivo provode prevencijske programe koji bi mogli poticati supružnike na rješavanje međusobnih problema prije nego predaju zahtjev za razvod braka. Moramo naglasiti kako u ovom istraživanju nije uključen podatak o supružnicima koji su se uključili u neki oblik savjetovanja/terapije prije pokretanja razvoda braka. Istraživanja su pokazala da se obiteljskom medijacijom može postići poboljšanje komunikacije između članova obitelji, smanjenje sukoba te postizanje sporazuma. Ukoliko se i ne postigne sporazum, medijacijski proces je koristan - osigurava bolje uvjete komunikacije, povećava međusobno razumijevanje uključenih pojedinaca, pruža značajno iskustvo učenja kako pregovarati i iskustvo postizanja sporazuma u teškoj situaciji te omogućava da se održi obiteljski sustav donošenja odluka i zadrži odgovornost za kvalitetu života članova obitelji (Sladović Franz, 2005.). Upravo kroz obiteljsku medijaciju, članovi obitelji uče učinkovitije komunicirati i pregovarati kako bi se osnažili za kvalitetnije održavanje budućih obiteljskih odnosa, neovisno o promjenama i reorganizaciji obiteljskog života (Breber i Sladović Franz, 2014.). 


\section{Emocionalno udaljavanje}

Praksa provođenja postupka posredovanja pokazala je da emocionalno udaljavanje kao razlog razvoda najčešće navode parovi/ supružnici koji zapravo nisu spremni razgovarati o »pravim« razlozima razvoda braka. Pitanje je zapravo što se skriva iza ovakve izjave supružnika, što zapravo ostavlja prostor za raspravu. Ipak, potrebno je istaknuti kako stručnjaci u centrima za socijalnu skrb ne izvršavaju samo ulogu posredovatelja, već djeluju u mnogim drugim postupcima vezanim uz obitelji. U tom smislu, može se pretpostaviti kako supružnici koji dolaze u centre za socijalnu skrb razgovarati o svojim narušenim obiteljskim odnosima i razvodu braka, vjerojatno uzimaju u obzir uključenost djelatnika centra u njihovu problematiku i nakon razvoda braka (stručni tim centra za socijalnu skrb piše stručno mišljenje kao prijedlog sudu o uređenju pitanja koja proizlaze iz razvoda braka nakon postupka posredovanja). Navedeno može rezultirati opreznim verbaliziranjem supružnika o svojim relacijama, a primarno dosadašnjim lošim partnerskim odnosima koji su mogli negativno utjecati na ispunjavanje njihovih roditeljskih uloga, kako bi se na neki način "zaštitili« od dodatnih intervencija stručnih djelatnika u njihovoj obitelji i eventualnog daljnjeg tretmana u centru za socijalnu skrb. $U$ tom smislu, opetovano je vidljiv pozitivni aspekt obiteljske medijacije, odnosno nepristranog medijatora koji neće istodobno imati odgovornost praćenja određene obitelji ukoliko dođe do novih poteškoća. Zanimljivo bi bilo vidjeti kakvi bi rezultati istraživanja bili kada bi isto istraživanje bilo provedeno na reprezentativnom uzorku s mogućnošću anonimnog iznošenja podataka supružnika o bračnom odnosu i razlozima koji su doveli do njegovog prestanka.

\section{OGRANIČENJA ISTRAŽIVANJA}

lako je ovo istraživanje ponudilo relevantne rezultate za razumijevanje percepcije razvoda braka od strane supružnika i kako se ono odražava na postizanje sporazuma o roditeljskoj srbi, važno je osvrnuti se i na ograničenja istraživanja. Prvo, i najveće, ograničenje vezano je za odabir prigodnog uzorka, odnosno analizirana su stručna mišljenja u postupku posredovanja prije razvoda braka iz samo dvije (prigodno odabrane) godine te samo jedne podružnice Centra za socijalnu skrb Zagreb, što umanjuje mogućnost generalizacije dobivenih rezultata. Dodatno, diskriminativnom analizom po pitanju kriterija (sporazum o roditeljskoj skrbi), uspoređivan je neujednačen uzorak, što je u statističkom smislu moglo dovesti do propuštanja ukazivanja na značajne diskriminacijske varijable. Istraživanju zasigurno negativno pridonosi i mogućnost davanja socijalno poželjnih odgovora u vidu samoprocjene koju su vršili sudionici, kao i mogućnost davanja neutralnih odgo-

\section{2 članci}




\section{A. Štifter, M. Mihalj, L. Rajhvajn Bulat, S. Vuković: Razlozi razvoda braka ...}

vora i/ili (ne)iskrenosti odgovora kojim se ocrnjuje drugog partnera. U tom smislu, kao i za druga kvalitativna istraživanja, i ovo istraživanje ima generalne značajke ograničenja kvalitativne metodologije - nedovoljna kvantificiranost podataka, stoga smanjena objektivnost $\mathrm{i}$ interpretabilnost, mogućnost osobne pogreške istraživača, pristranost u procjeni istraživača, nepostojanje provjerenog instrumentarija te propusti u provedbi same metode (Milas, 2005.). Smatramo kako je važno nadalje provoditi istraživanja ovakvog tipa i problematike uz otklanjanje prethodno navedenih ograničenja, koja se primarno odnose na povećanje uzorka, uključenost većeg broja centara za socijalnu skrb po svim županijama Republike Hrvatske. Također, potrebno je navesti kako u ovom istraživanju nisu korišteni podaci vezani uz izvanbračne zajednice, kao što nije ispitana varijabla razilaženja u mišljenjima bračnih drugova po pitanju percipiranih razloga za razvod braka, što su jednako vrijedni i bitni podaci u aspektu praktičnih implikacija, kao i budućih istraživanja ovakve problematike.

Na kraju, potrebno je istaknuti kako rezultati i provedba ovog istraživanja, unatoč nedostacima, predstavljaju pozitivan doprinos dosadašnjem praktičnom radu u sustavu socijalne skrbi, kao i moguće implikacije za provedbu obiteljske medijacije.

\section{ZAKLJUČAK}

Dobiveni rezultati ukazuju kako se percipirani razlozi razvoda braka supružnika mogu tumačiti kroz tri teme - obilježja partnerskog odnosa (komunikacijski problemi, emocionalno udaljavanje, nedostatak emocionalne podrške i poštovanja, nedostatak instrumentalne podrške i partnersko nasilje), vanjske okolnosti (financijski problem, partnerovi roditelji kao izvor sukoba i roditeljstvo kao izvor sukoba) te individualne osobine bračnih partnera (neusklađenost partnerskih očekivanja i emocionalni/psihički problemi pojedinca), te kroz dodatnu zasebnu kategoriju pod nazivom - nevjera. Komunikacijski problemi, emocionalno udaljavanje, nedostatak emocionalne podrške i poštovanja i neusklađenost partnerskih očekivanja su od navedenih razloga razvoda braka najčešće navođeni od strane partnera, tj. najzastupljeniji.

Žene statistički značajno više od muškaraca kao razloge razvoda navode nedostatak instrumentalne podrške, partnersko nasilje te emocionalne/psihičke probleme pojedinca, dok se niti za jedan razlog nije pokazalo da ga statistički značajno više navode muškarci. Za ostale razloge, između muškaraca i žena također ne postoji statistički značajna razlika u proporciji njihovog navođenja. Ukoliko se pogledaju ukupni razlozi po temama, i muškarci i žene kao najčešće razloge razvoda braka navode obilježja partnerskog odnosa. 
Diskriminativna analiza ukazuje kako varijable koje najbolje razlikuju bračne partnere koji su postigli sporazum o roditeljskoj skrbi od onih koji ga nisu postigli jesu procjena stručnjaka o spremnosti supružnika na suradnju oko roditeljske skrbi te razlozi razvoda braka, odnosno partnersko nasilje, emocionalni/psihički problemi pojedinca, komunikacijski problemi i emocionalno udaljavanje.

Upravo ove dobivene varijable ukazuju na važnost da se tijekom postupka obveznog savjetovanja, kao i provođenja predmedijacijskog postupka pažljivo procijeni jesu li ostvarene pretpostavke za ulazak u obiteljsku medijaciju - spremnost na suradnju, kompetentnost i ravnoteža moći, budući da će bez ostvarenih pretpostavki obiteljska medijacija vjerojatno biti neuspješna, a može biti opasna po sigurnost (ako postoji velik rizik od obiteljskog nasilja) i prava sudionika (ako osoba uslijed emocionalnih i/li psihičkih problema nije u stanju zastupati svoje interese), tj. potrebno je dobro procijeniti koji bi postupak bio prikladniji da se osiguraju prava i potrebe ranjive stranke ili djeteta.

Dobiveni rezultati nadalje ukazuju kako supružnici uključeni u ovo istraživanje iskazuju određeni negativni obrazac u svojem bračnom životu, koji primarno uključuje najčešće navođene razloge razvoda braka, odnosno komunikacijske probleme, emocionalno udaljavanje, nedostatak međusobne podrške i neusklađenost $u$ očekivanjima partnera.

Vidljivo je da se razlozi braka koji su najčešće navođeni, odnosno komunikacijski problemi i emocionalno udaljavanje, kasnije očito odražavaju i tijekom postupka razvoda braka u smislu nemogućnosti supružnika da postignu sporazum o roditeljskoj skrbi.

U tom kontekstu, jasno se ističe potreba za dodatnom edukacijom supružnika u području učinkovitih vještina komuniciranja, pregovaranja, konstruktivnog rješavanja sukoba te usmjeravanje supružnika na kvalitetnije uočavanje i razumijevanje potreba i očekivanja onog drugog u odnosu. Uz potrebu različitih preventivnih i intervencijskih programa koji postoje, treba istaknuti i mogućnost upotrebe obiteljske medijacije i u preventivnom, kao i intervencijskom smislu. Naime, budući da obiteljska medijacija kroz svoju strukturu i pravila rada može osigurati međusobno poštovanje, jednakost i pravednost te olakšati komunikaciju između sukobljenih strana, može pomoći supružnicima da nauče kvalitetno rješavati konkretne sukobe te na taj način eventualno povećati njihovo zadovoljstvo bračnim životom što može utjecati i na odluku o pokretanju razvoda. S druge strane, ukoliko supružnici i pokrenu razvod braka, mogu uz pomoć obiteljske medijacije postići sporazum o roditeljskoj skrbi, tj. zajednički plan roditeljstva, kao i razviti trajno roditeljsko partnerstvo uslijed zajedničkog interesa za dobrobit djece.

\section{4 članci}




\section{LITERATURA}

1. Ajduković, M. \& Sladović Franz, B. (2003). Razumijevanje sukoba. U: Ajduković, D. (ur.), Socijalna rekonstrukcija zajednice. Zagreb: Društvo za psihološku pomoć, 195-210.

2. Alinčić, M. (1999). Europsko viđenje postupka obiteljskog posredovanja. Revija za socijalnu politiku, 6 (3-4), 227-240.

3. Amato, P. R. (2001). Children of divorce in the 1990s: An update of the Amato and Keith (1991) meta-analysis. Journal of Family Psychology, 15 (3), 355370.

4. Amato, P. R. \& Previti, D. (2003). Peoples reasons for divorcing. Journal of Family Issues, 24 (5), 602-626.

5. Amato, P. R. \& Cheadle, J. (2005). The long reach of divorce: Divorce and child well-being accros three generation. Journal of Marriage and Family, 67 (1), 191-206.

6. Beck, C. J. A., Walsh, M. E. \&Weston, R. (2009). Analysis of mediation agreaments of families reporting specific types of intimate partner abuse. Family Court Review, 47 (3), 401-415.

7. Blažeka Kokorić, S. (2007). Rješavanje partnerskih sukoba s obzirom na spol partnera, iskustvo i trajanje partnerskog odnosa. Ljetopis socijalnog rada, 14 (1), 5-26.

8. Breber, M. \& Sladović Franz, B. (2014). Uvođenje obiteljske medijacije u sustav socijalne skrbi - Perspektiva stručnjaka. Ljetopis socijalnog rada, 21 (1), 121150.

9. Clark, W. \& Crompton, S. (2006). Till death do us part? The risk of first and second marriage dissolution. Statistics Canada, Catalogue No. 11- 008, 81, 2333.

10. Clarke, G. \& Davies, I. (1992). Mediation - When it is not an appropriate dispute resolution process? Australian Dispute Resolution Journal, 5 (1), 42-48.

11. Cohen, O. (2012). Agreement reached through court mediation conducted by social workers: Impact on the co-parenting relationship. British Journal of Social Work, 42 (2), 227-244.

12. Čudina Obradović, V. \& Obradović, J. (1999). Living in abusive family relationships. Društvena istraživanja, 42 (4), 475-495.

13. de Graaf, P. M. \& Kalmijn, M. (2006). Divorce motives in a period of rising divorce. Journal of Family Issues, 27 (4), 483-505.

14. Državni zavod za statistiku (2014). Statistički ljetopis Republike Hrvatske 2014. Zagreb: Državni zavod za statistiku.

15. Finley, G. E. \& Schwartz, S. J. (2010). The divided world of the child: Divorce and long-term psychosocial adjustmen. Family Court Review, 48 (3), 516-527. 
16. Flynn, D. (2005). The social worker as family mediator: Balancing power in cases involving family violence. Australian Social Work, 58 (4), 407-418.

17. Gribben, S. (1990). Mediation of family disputes. Australian Journal of Family Law, 5 (2), 126-136.

18. Härkönen, J. (2013). Divorce: Trends, patterns, causes, consequences. (Working Paper 2013:3). Stockholm: Stockholm University Linnaeus Center on Social Policy and Family Dynamics in Europe, SpaDE.

19. Hughes, R. Jr. (2009). The effects of divorce on children. Urbana: University of Illinois.

20. Kelly, J. B. (1995). Power imbalance in divorce and interpersonal mediation: Assessment and intervention. Mediation Quarterly, 13 (12), 85-98.

21. Kelly, J. B. (2004). Family mediation research: Is there empirical support for the end?. Conflict Resolution Quarterly, 22 (1-2), 3-35.

22. Kelly, J. B. \& Johnson, M. P. (2008). Differentiation among types of intimate partner violence: Research update and implications for interventions. Family Court Review, 46 (3), 476-499.

23. Laklija, M., Pećnik, N. \& Šarić, R. (2005). Zaštita najboljeg interesa djeteta u postupku razvoda braka roditelja. Ljetopis socijalnog rada, 12 (1), 7-38.

24. Majstorović, I. (2007). Posredovanje prije razvoda braka: Hrvatsko pravo i europska rješenja. Zbornik PFZ, 57 (2), 405-456.

25. Mathis, R. D. \& Tanner, Z. (1998). Effect of unscreended spouse violence on mediated agreements. The American Journal of Family Therapy, 26, 251-160.

26. McCloskey, L. A., Figueredo, A. J. \& Koss, M. P. (1995). The effects of systemic family violence on childrens mental health. Child Development, 66, 1239-1261.

27. Milas, G. (2005). Istraživačke metode u psihologiji i drugim društvenim znanostima. Jastrebarsko: Naklada Slap.

28. Obiteljski zakon (2003, 2004, 2007, 2011, 2013). Narodne novine, 116/2003., 17/2004., 136/2004., 107/2007., 57/2011., 61/2011., 25/2013.

29. Obiteljski zakon (2015). Narodne novine, 103/2015.

30. Sladović Franz, B. (2005). Obilježja obiteljske medijacije. Ljetopis socijalnog rada, 12 (2), 301-319.

31. Sladović Franz, B. (2010). Medijacija i socijalni rad. Radni materijal.

32. Tabachnick, B. G. \& Fidell, L. S. (2007). Using multivariate statistics. Boston: Pearson/Allyn \& Bacon.

33. Walton, L., Oliver, C. \& Griffin, C. (1999). Divorce mediation: The impact of mediation on the psychological well-being of children and parents. Journal of Community and Applied Social Psychology, 9 (1), 35-46.

34. Wolcott, I. \& Hughes, J. (1999). Towards understanding the reasons for divorce. Working Paper No.20. Melbourne: Australian Institute of Family Studies. 


\section{A. Štifter, M. Mihalj, L. Rajhvajn Bulat, S. Vuković: Razlozi razvoda braka ...}

Ana Štifter

Marko Mihalj

Social Welfare Centre Zagreb

Linda Rajhvajn Bulat

University of Zagreb

Faculty of Law

Department of Social Work

\section{Silvia Vuković}

Home for children and adults victims of family violence »Rainbow - Zagreb»

\section{DIVORCE REASONS AS DETERMINANTS OF PARENTAL CARE AGREEMENT}

\section{ABSTRACT}

In the recent decades, the rate of divorce has increased significantly in the Western world. This study aims to answer the following questions: what are the reasons that led to divorce from the perspective of the spouses in the mediation process (1); are there gender differences in their perception of those reasons (2); which variables can be used to distinguish between married couples who achieve agreement on parental care and those who do not (3).

In 2010 and 2013, Social Welfare Centre Zagreb, office Sesvete, conducted a problem description analysis of 177 expert opinions gathered in mediation processes.

The results have shown that the spouses stated the following reasons that lead to divorce: communication problems, emotional distancing, lack of emotional support and respect, incompatibility of expectations, lack of instrumental support, partner violence, financial problems, partner's parents as a source of conflict, parenting as a source of conflict, emotional/ psychological problems of the individual and infidelity. Of all these causes, the first four were the most frequently stated and were the most common. However, lack of instrumental support, partner violence and emotional/psychological problems of the individual are reasons that are statistically more significantly reported by women than by men. None of the reasons was statistically more significantly reported by men.

The variables that best differentiate between the parents who have reached an agreement on parental care and those who have not are the following: expert assessment of cooperation between parents regarding parental care, partner violence, communication and emotional/psychological problems, and emotional distancing.

Also, the importance of the obtained significant variables relies on the possible implications for the use of family mediation in practice.

Key words: divorce, reasons for divorce, mediation, family mediation, parental care agreement. 
